\title{
Anxiety in English Language Learning: A Case Study of English Language Learners in Saudi Arabia
}

\author{
Jamilah Mohammed Sadiq ${ }^{1}$ \\ ${ }^{1}$ College of Education Princess Norah University, Saudi Arabia \\ Correspondence: Jamilah Mohammed Sadiq, College of Education Princess Norah University, Saudi Arabia. \\ E-mail: jmmaashy@pnu.edu.sa
}

Received: February 3, 2017 Accepted: May 25, 2017 Online Published: May 30, 2017

doi: 10.5539/elt.v10n7p1 URL: http://doi.org/10.5539/elt.v10n7p1

\begin{abstract}
Language anxiety as a specific aspect of language acquisition has occupied a great body of research for the past few decades. In this study, the level of foreign language anxiety among English language learners was investigated. This study was carried out with a quantitative research design using a survey methodology to collect data about the participants' language anxiety. The sample of the study included 100 university students from the college of Education at Princess Nora University in the Kingdom of Saudi Arabia. The participants were randomly selected. For this research study, Foreign Language Classroom Anxiety Scale developed by Horwitz, Horwitz, and Cope (1986) was used to collect the research data. Based on the findings of the study, several implications are highlighted.
\end{abstract}

Keywords: English language students, anxiety, classroom, age, Princess Nora

\section{Introduction}

Second or foreign language education has expanded rapidly during the last few decades in Saudi Arabia and many English language courses are offered from primary to advanced levels at many schools, institutions and universities. Many English language learners in Saudi Arabia and around the world still have difficulty in comprehending and employing English language skills. Thus, many researches haven been conducted to determine the relationship between language anxiety and achievement in the target language. Language anxiety is not a new phenomenon. Language anxiety as a specific aspect of language acquisition has occupied a great body of research for the past few decades. Language anxiety has long been recognized as an obstacle in second or foreign language learning. In other words, language anxiety is a negative emotional state; therefore, it can have a negative impact on how to learn or acquire the target language. Language anxiety, recognized as an affective factor in foreign language learning (Gardner \& MacIntyre, 1992).

\subsection{English Language in KSA}

Today, English is one of the most important languages in the world. Further, English today is needed almost everywhere. In Saudi Arabia, Arabic is the official language, it is the language of instruction and communication at all levels. On the other hand, English language is well known as a foreign language, it is the most studied foreign language in Saudi Arabia at all education levels. A foreign language is "one that is learned in a place where the language is not typically used as the medium of ordinary communication" (Oxford \& Shearin 1994, p. 14).

\subsection{Language Anxiety}

Language anxiety has occupied a great body of research for the past few decades. Previous research findings on language anxiety have revealed the fact that anxiety can impede foreign language performance and its production. In most of the time, the language learners are facing some kinds of problems in learning a new language. Language anxiety has long been recognized as an obstacle in second language learning. Khattak, Jamshed, Ahmad, Mirza and Baig (2011) reported, "Anxiety experienced in learning English language can be debilitating and may influence students' achievements of their goals". In the other words, anxiety is one of the most significant factors affecting language learning. High level of language anxiety is correlated with poor performance in language learning. The experience of language anxiety varies from learner to learner. According to Ying (2008), language anxiety is caused by (1) personal and interpersonal, (2) learner beliefs about language 
learning, (3) teacher belief about language anxiety, (4) teacher-learner interactions, (5) classroom procedures, and (6) language testing.

The literature on language anxiety has offered several definitions of foreign language anxiety. Sanders and Wills (2003) described anxiety in general as "a complex, multifaceted experience, a feeling which comes flooding into our whole selves, affecting many different aspects of our being". Foreign language anxiety defined as the "worry and negative emotional reaction aroused when learning or utilizing a second language" (Young, 1999). Likewise, language anxiety is defined as "a distinct complex of self-perceptions, beliefs, feelings, and behaviors related to classroom language learning arising from the uniqueness of the language learning process" (Horwitz, Horwitz, \& Cope, 1986). MacIntyre and Gardner (1994) have also provided a very similar definition of language anxiety, they believe that language anxiety is "the feeling of tension and apprehension specially associated with second language contexts, including speaking, listening, and writing".

Language research has showed the effect of language anxiety on students' achievement and performance in English language learning. Early studies learning found a strong relationship between language anxiety and language learning and achievement (Horwitz et. al., 1986). If a student he or she feels anxious in the classroom, the possibility of having a frustrating and bad experience with the foreign language increases (Gregersen \& Horwitz, 2002). Ewald (2007) found that high levels of anxiety usually had a negative effect on the language acquisition process. Language learners who experienced language anxiety will lead them to feeling of worried about failing. Yan and Horwitz (2008) conducted a study to examine the factors associated with students' anxiety in language learning in China and founded that comparison with peers, learning strategies, and language learning interest and motivation were the most immediate factors. Another study conducted by Woodrow (2006) to examine the correlation between anxiety and language performance among EFL learners who attended English for Academic Purposes (EAP) courses. The findings indicate that the most frequent reported cause of anxiety was fear of interacting with native speakers, giving oral presentations and performing in front of classmates. Language anxiety also is a strong indicator of negative attitudes towards language learning. Chao (2003) conducted a study that employed both qualitative and quantitative methods to investigate the level of anxiety among private college students who learned English as a foreign language in Taiwan. The findings of this study revealed that the level anxiety was moderately high. Onwuegbuzie, Baily and Daley (1999) examined the factors predicted foreign language anxiety and found significant relations between the following variables: age, academic achievement, prior high school experience with foreign languages, and expected overall average for current language course. In terms of students age it was found that older students had higher language anxiety than did younger students.

\subsection{Writing Anxiety}

Language anxiety causes students' negative attitudes towards the foreign language writing skill. Writing anxiety has an effect on students' writing performance. Writing anxiety is considered as a barrier for enhancing English language learning and performance. Cheng (1997) found a negative correlation between FL writing anxiety and FL writing achievement. Cheng (2002) believes that writers with higher level of anxiety tend to avoid taking writing courses. Horwitz et al. (1986) indicated that students with higher writing anxiety write shorter compositions, have difficulty concentrating and grasping the content of input, have problems discriminating the sounds and structure, become forgetful, or even over-study.

\subsection{Reading Anxiety}

English language reading anxiety is the fear experienced by students when reading English text. Reading anxiety has an effect on students' academic performance. Reading anxiety is basically rooted in some type of fear such as fear of failure and lack of self confidence. Recent studies confirmed a negative correlation between language anxiety and reading performance. Chen (2007) found second language speaking anxiety negatively correlated with oral performance.

\subsection{Speaking Anxiety}

Speaking is one of the fundamental skills of language learning. In second or foreign language education, speaking anxiety has a detrimental effect on learners' performance. Speaking anxiety is rooted in lack of self-confidence. According to Horwitz, Horwitz, and Cope (1986), speaking is arguably the skill most affected by language anxiety. Furthermore, EFL or ESL teachers play an important role in the amount of anxiety students experienced in language classes. Williams and Andrade (2008) found that asking questions by EFL or ESL teachers' in classrooms make students anxious. According to Elkhafaifi (2005), anxious students tend to avoid voluntary answers and participation in oral activities and avoiding speaking in classroom. In a study conducted by Price (1991), the researcher interviewed highly anxious learners of French and found that learners sources of 
anxiety were as following; (1) fear of speaking the target language in front of their peers, (2) fear of making mistakes, (3) being laughed at by others, and (4) learners perceptions that their French language skills are weaker than those of other students.

\subsection{Listening Anxiety}

Listening skill is a fundamental for language acquisition. The concept of foreign language listening anxiety is associated with general foreign language anxiety. Foreign language listening anxiety is one of the important learner variables affecting success and failure in foreign language learning. Previous researches indicated that listening skill is a crucial factor in language acquisition. Vogely (1998) conducted a study to investigate the relationship between learners' listening performance and anxiety among 140 American university students studying Spanish. The findings revealed that the majority of the participants had experienced anxiety while listening to Spanish. Open-ended questions were asked after a listening comprehension examination. The results indicated that, the source sources of anxiety were as following, (1) the speed of delivery; (2) poor enunciation; (3) unfamiliar intonation; (4) different accents, and; (5) the length of the listening passages. In sum language, anxiety has been recognized as one of the fundamental affective variables influencing success or failure in language learning.

\subsection{Research Questions}

The research questions of this study are as follows:

1) What is the level of language anxiety among EFL students in the faculty of education at Princes Nora University?

2) Are there any significant relation between the level of language anxiety and the following variables: (a) year in the specific program, and (b) students age?

\section{Method}

A quantitative research method was adopted in this study to investigate the level of language anxiety among EFL students in Saudi Arabia.

\subsection{Research Design}

It is well known that, the level of language anxiety is measured by a number of researchers using several instruments. In the current study, a survey research methodology was used to collect data about the level of language anxiety.

\subsection{Sample}

To accomplish the objectives of this study, the researcher selected a total of 100 students learning English for BA degree at the Princes Nora University in the kingdom of Saudi Arabia. All participants were Saudi students whose mother tongue is Arabic. They were all majoring in the field of English language. Sample selected by the method of random sampling. They took the research instruments as their class activities and consented to the collection of data from their responses to the questionnaires.

\subsection{Data Collection Instrument}

Data were collected through questionnaires. For this research study, Foreign Language Classroom Anxiety Scale developed by Horwitz, Horwitz, and Cope (1986) was used to collect the research data. There were 35 items in this instrument, 2 related with personal information, and 33 items related with foreign language classroom anxiety are on a series five-point Likert-scale as follows: Strongly Disagree (1), Disagree (2), Neither Agree nor Disagree (3), Agree (4), Strongly Agree (5). A pilot study was conducted to ascertain the effectiveness of instruments. The instrument enjoyed high reliability. Its reliability was reported to be 0.85 . The scores of language anxiety were divided into three levels: namely low mean score, moderate mean score and high mean score.

\subsubsection{Procedures}

The investigation of this study was an attempt to answer the questions dealing with level of language anxiety among English language learners. The study took place in the academic year 2015-2016. The participants were asked to answer all the items in the questionnaire. Once data has been collected, the participants' responses were analyzed using Statistical Package for the Social Sciences Programs (SPSS) version 22.0. Various statistical analyses including both descriptive and inferential were used to analyze the data. 


\section{Data Analysis}

English language students received a survey questionnaire, and the usable response rate was $70 \%$. The data collected was processed by using Statistical Package for Social Science (SPSS) program. It was used to analyze data as follows:

1) The descriptive statistics was used in summing the data included frequency percentages, means, and standard deviations.

2) Pearson's correlation coefficients were used to identify the differences in the level of language anxiety according to age and the year in the specific program.

\subsection{Demographic Variables}

Demographic information of the participating students are shown with respect to age in Table 1, and with respect to students' year in the specific program in Table 2.

Table. 1 Distribution of the participants with respect to age

\begin{tabular}{llll}
\hline Age Groups & Frequency & Percent & Valid Percent \\
\hline $18-21$ & 50 & 50.0 & 50.0 \\
$22-25$ & 43 & 43.0 & 43.0 \\
$26-29$ & 4 & 4.0 & 4.0 \\
Older Than 30 & 3 & 3.0 & 3.0 \\
Total & 100 & 100.0 & 100.0 \\
\hline
\end{tabular}

Table 1, shows the distribution of the participants according to their age. As shown in Table 2 the highest percentage of participants $(50.0 \%)$ were between the age of $18-21,(43.0 \%)$ were between the age of $22-25$, $(4.0 \%)$ were between the age of $26-29$, while the lowest percentage $(3.0 \%)$ was for the participants who are older than 30 .

Table. 2 Distribution of the participants with respect to year in the specific program

\begin{tabular}{llll}
\hline & Frequency & Percent & Valid Percent \\
\hline First Year & 35 & 35.0 & 35.0 \\
Second Year & 32 & 32.0 & 32.0 \\
Third Year & 16 & 16.0 & 16.0 \\
Fourth Year & 17 & 17.0 & 17.0 \\
Total & 100 & 100.0 & 100.0 \\
\hline
\end{tabular}

It is shown in Table 2, that $35.0 \%$ of the participants are first year, $32.0 \%$ of them are second year, $16.0 \%$ of the participants are third year while fourth year are $17.0 \%$.

\subsection{Results Related to Question One}

For the purpose of answering question number one, respondents were asked to respond to 33 Likert-scale items measuring the level of language anxiety among EFL students. The results of descriptive analysis (Means, Std. Deviations, and Percentages) were presented in Table 3. 
Table 3. Means, Std. Deviations, and Percentages

\begin{tabular}{|c|c|c|c|c|c|c|c|}
\hline Items & Percent & & & & & & \\
\hline & SD & $\mathrm{D}$ & $\mathrm{N}$ & A & SA & Mean & Std \\
\hline Item 1 & $22.0 \%$ & $17.0 \%$ & $18.0 \%$ & $17.0 \%$ & $26.0 \%$ & 3.08 & 1.50 \\
\hline Item 2 & $44.0 \%$ & $23.0 \%$ & $10.0 \%$ & $13.0 \%$ & $10.0 \%$ & 2.22 & 1.38 \\
\hline Item 3 & $13.0 \%$ & $11.0 \%$ & $8.0 \%$ & $38.0 \%$ & $30.0 \%$ & 3.61 & 1.36 \\
\hline Item 4 & $18.0 \%$ & $7.0 \%$ & $15.0 \%$ & $34.0 \%$ & $26.0 \%$ & 3.43 & 1.41 \\
\hline Item 5 & $29.0 \%$ & $28.0 \%$ & $21.0 \%$ & $11.0 \%$ & $11.0 \%$ & 2.47 & 1.31 \\
\hline Item 6 & $11.0 \%$ & $8.0 \%$ & $14.0 \%$ & $37.0 \%$ & $30.0 \%$ & 3.67 & 1.28 \\
\hline Item 7 & $9.0 \%$ & $7.0 \%$ & $27.0 \%$ & $30.0 \%$ & $27.0 \%$ & 3.59 & 1.21 \\
\hline Item 8 & $42.0 \%$ & $21.0 \%$ & $15.0 \%$ & $11.0 \%$ & $11.0 \%$ & 2.28 & 1.39 \\
\hline Item 9 & $9.0 \%$ & $7.0 \%$ & $27.0 \%$ & $33.0 \%$ & $24.0 \%$ & 3.56 & 1.91 \\
\hline Item 10 & $13.0 \%$ & $6.0 \%$ & $38.0 \%$ & $18.0 \%$ & $25.0 \%$ & 3.36 & 1.28 \\
\hline Item 11 & $25.0 \%$ & $15.0 \%$ & $45.0 \%$ & $6.0 \%$ & $9.0 \%$ & 2.59 & 1.18 \\
\hline Item 12 & $12.0 \%$ & $13.0 \%$ & $16.0 \%$ & $39.0 \%$ & $20.0 \%$ & 3.42 & 1.28 \\
\hline Item 13 & $10.0 \%$ & $12.0 \%$ & $25.0 \%$ & $32.0 \%$ & $21.0 \%$ & 3.42 & 1.23 \\
\hline Item 14 & $14.0 \%$ & $6.0 \%$ & $23.0 \%$ & $30.0 \%$ & $27.0 \%$ & 3.50 & 1.32 \\
\hline Item 15 & $22.0 \%$ & $12.0 \%$ & $20.0 \%$ & $22.0 \%$ & $24.0 \%$ & 3.14 & 1.47 \\
\hline Item 16 & $39.0 \%$ & $28.0 \%$ & $12.0 \%$ & $13.0 \%$ & $8.0 \%$ & 3.23 & 1.30 \\
\hline Item 17 & $22.0 \%$ & $14.0 \%$ & $27.0 \%$ & $25.0 \%$ & $12.0 \%$ & 2.91 & 1.32 \\
\hline Item 18 & $21.0 \%$ & $20.0 \%$ & $23.0 \%$ & $20.0 \%$ & $16.0 \%$ & 2.90 & 1.37 \\
\hline Item 19 & $33.0 \%$ & $30.0 \%$ & $23.0 \%$ & $11.0 \%$ & $3.0 \%$ & 2.21 & 1.11 \\
\hline Item 20 & $17.0 \%$ & $20.0 \%$ & $26.0 \%$ & $21.0 \%$ & $16.0 \%$ & 2.99 & 1.32 \\
\hline Item 21 & $33.0 \%$ & $27.0 \%$ & $16.0 \%$ & $12.0 \%$ & $12.0 \%$ & 2.43 & 1.37 \\
\hline Item 22 & $11.0 \%$ & $12.0 \%$ & $31.0 \%$ & $34.0 \%$ & $12.0 \%$ & 3.24 & 1.15 \\
\hline Item 23 & $14.0 \%$ & $12.0 \%$ & $16.0 \%$ & $43.0 \%$ & $15.0 \%$ & 3.33 & 1.27 \\
\hline Item 24 & $16.0 \%$ & $18.0 \%$ & $36.0 \%$ & $23.0 \%$ & $7.0 \%$ & 2.87 & 1.15 \\
\hline Item 25 & $13.0 \%$ & $12.0 \%$ & $31.0 \%$ & $16.0 \%$ & $28.0 \%$ & 3.34 & 1.35 \\
\hline Item 26 & $16.0 \%$ & $17.0 \%$ & $19.0 \%$ & $34.0 \%$ & $14.0 \%$ & 3.13 & 1.35 \\
\hline
\end{tabular}

Examination of the Means, Std. Deviations and Percentages in Table 3, confirms that the highest Percentages of scores in language anxiety were, "During the class, I find myself thinking about things that have nothing to do with the course". $67.0 \%$ of the participants answered that they either ("agree" or "strongly agree"), with Mean score $(\mathrm{M}=3.67)$, and Std. Deviation $(\mathrm{SD}=1.28)$, "I tremble when I know that I'm going to be called on in language class". $68.0 \%$ of the participants answered that they either they either ("agree" or "strongly agree"), with Mean score $(\mathrm{M}=3.61)$, and Std. Deviation ( $\mathrm{SD}=1.36)$, "I keep thinking that the other students are better at languages than I am". $57.0 \%$ of the participants answered that they either ("agree" or "strongly agree"), with Mean score $(\mathrm{M}=3.59)$, and Std. Deviation $(\mathrm{SD}=1.21)$, and "I start to panic when I have to speak without preparation in language class". $57.0 \%$ of the participants answered that they either ("agree" or "strongly agree"), with Mean score $(\mathrm{M}=3.56)$, and Std. Deviation ( $\mathrm{SD}=1.91)$.

The lowest Percentages of scores in language anxiety were scored: for the items "The more I study for a language test, the more confused I get". $50.0 \%$ of the participants answered that they either ("strongly disagree" or "disagree"), with Mean score ( $\mathrm{M}=2.43)$, and Std. Deviation ( $\mathrm{SD}=1.37)$, "I am usually at ease during tests in my language class". $63.0 \%$ of the participants answered that they either ("strongly disagree" or "disagree"), with Mean score ( $\mathrm{M}=2.28)$, and Std. Deviation ( $\mathrm{SD}=1.39)$, "I don't worry about making mistakes in language class." $77.0 \%$ of the participants answered that they ("strongly disagree" or "disagree"), with Mean score (M=2.22), and 
Std. Deviation ( $\mathrm{SD}=1.38)$, and "I am afraid that my language teacher is ready to correct every mistake I make." $60.0 \%$ of the participants answered that they either ("strongly disagree" or "disagree"), with Mean score $(\mathrm{M}=2.21)$, and Std. Deviation ( $\mathrm{SD}=1.11)$. The overall average of the Mean scores of the level of language anxiety was $(\mathrm{M}=3.03)$ and the Std. Deviation $(\mathrm{SD}=0.24)$ confirming the results of the Percentages reveal that most of the respondents experienced a moderate level of anxiety in the language class. In other words, EFL students in general they do not feel too anxious about learning the English language, though they are still anxious in certain situations.

\subsection{Results Related to Question Two}

ANOVA was implemented with the purpose of testing whether there are meaningful differences in the level of language anxiety according to age and the year in the specific program.

Table 4. The one way ANOVA results according to EFL students demographic variables

\begin{tabular}{lllllll}
\hline & & Sum of Squares & df & Mean Square & F & Sig. \\
\hline Age & Between Groups & 195,356 & 4 & 48,839 & $2,434^{*}$ & 048 \\
& Within Groups & 5699,357 & 96 & 20,068 & & \\
& Total & 5894,713 & 100 & & & \\
& Between Groups & 50,613 & 4 & & & \\
\hline Year in the specific program & Within Groups & 5844,100 & 96 & 12,653 & \multirow{2}{*}{615} & \multirow{2}{*}{, 652} \\
& Total & 5894,713 & 100 & 20,578 & & \\
\hline
\end{tabular}

According to Table 4, there is no meaningful difference between averages in terms of the year in the specific program variables. There is a meaningful difference of 0.05 level between averages in terms of age variable.

\section{Conclusion}

Anxiety is one form of emotional problem that could highly affect the academic performance of EFL Learners. The findings of this study suggest that EFL students experience moderate level of anxiety. This result is in line with most of the previous studies Heng, Abdullah and Yosaf (2012), and Çatatay (2015). Besides this, the findings also indicate no significant difference of anxiety level with respect to year of the specific program. This finding is in contrast with Elkhafaifi (2005) findings, who found that students in the third year of their study had significantly lower levels of foreign language anxiety than those in the first and second year of their study. However, th0e findings indicate that there is a meaningful difference in the level of language anxiety in terms of age variable. Based on the findings the following recommendations were made, (1) faculty staff should acknowledge the importance of the issue of language anxiety among the EFL learners, (2) English-language learners should be encouraged to practice English language inside and outside the classroom, and (3) English-language learners should be encouraged to communicate with native speakers in more informal contexts such as social networking.

\section{References}

Çatatay, V. (2015). Examining EFL students' foreign language speaking anxiety: The case at a Turkish state university. Procedia - Social and Behavioral Sciences, 199, 648-656. https://doi.org/10.1016/j.sbspro.2015.07.594

Chao, C. (2003). Foreign language anxiety and emotional intelligence: A study of EFL students in Taiwan. Texas $\begin{array}{llllll}\text { A } & \& & \text { M } & \text { University-Kingsville. } & \text { Retrieved }\end{array}$ http://ezproxy.lib.uh.edu/Login?URL=/docview/305244027? accountid=7107

Chen, M. L. (2007). Test anxiety, reading anxiety and reading performance among university English as second language learners Unpublished M.A. thesis, Ming Chuan University, Taiwan.

Cheng, H. (1997). The impacts of teachers' beliefs on students' anxiety about foreign language learning. The Proceedings of the Sixth International Symposium on English Teaching. Taipei, Crane, 113-129.

Cheng, Y. S. (2002). Factors associated with foreign language writing anxiety. Foreign Language Annals, 35, 
647-656. https://doi.org/10.1111/j.1944-9720.2002.tb01903.x

Elkhafaifi, H. (2005). Listening comprehension anxiety in the Arabic language classroom. The Modem Language Journal, 89(2), 206-220. https://doi.org/10.1111/j.1540-4781.2005.00275.x

Ewald, J. D. (2007). Foreign language learning anxiety in upper-level classes: Involving students as researchers. Foreign Language Annals, 40(1), 122-142. https://doi.org/10.1111/j.1944-9720.2007.tb02857.x

Gardner, R. C., \& MacIntyre, P. D. (1992). A student's contributions to second language learning. Part I: Cognitive variables. Language Teaching, 25, 211-22. https://doi.org/10.1017/S026144480000700X

Heng, C. S., Abdullah, A. N., \& Yosaf, N. B. (2012). Investigating the construct of anxiety in relation to speaking skills among ESL tertiary learners. 3L: The Southeast Asian Journal of English Language Studies, 18(3), $155-166$.

Horwitz, E. K., Horwitz, M. B., \& Cope, J. A. (1986). Foreign language classroom anxiety. The Modern language Journal, 70(2), 125-132. https://doi.org/10.1111/j.1540-4781.1986.tb05256.x

MacIntyre, P. D., \& Gardner, R. C. (1994). The effects of induced anxiety on three stages of cognitive processing in computerized vocabulary learning. Studies in Second Language Acquisition, 16, 1-17. https://doi.org/10.1017/S0272263100012560

Onwuegbuzie, A. J., Bailey, P., \& Daley, C. E. (1999). Factors associated with foreign language anxiety. Applied Psycho-Linguistics, 20, 217-239. https://doi.org/10.1017/s0142716499002039

Oxford, R., \& Shearin, J. (1994). Language learning motivation: Expanding the theoretical framework. Modem Language Journal, 78, 12-28. https://doi.org/10.1111/j.1540-4781.1994.tb02011.x

Price, M. L. (1991). The subjective experience of foreign language anxiety: Interview with highly anxious students. Language anxiety: From theory and research to classroom implications. In E. K. Horwitz, \& D. J. Young (Eds.),. Englewood Cliffs, NJ, Prentice Hall: 101-108.

Sanders, D., \& Wills, F. (2003). Counselling for anxiety problems (2nd ed.). London: Sage.

Vogely, A. J. (1998). Listening comprehension anxiety: Students' reported sources and solutions. Foreign Language Annals, 31(1), 67-80. https://doi.org/10.1111/j.1944-9720.1998.tb01333.x

Williams, K. E., \& Andrade, M. R. (2008). Foreign language anxiety in Japanese EFL university classes: Causes, coping, and locus of control. Electronic Journal of Foreign Language Teaching, 5(2), 181-191.

Woodrow, L. (2006). Anxiety and speaking English as a second language. RELC Journal, 37(3), 308-328. https://doi.org/10.1177/0033688206071315

Yan, J. X., \& Horwitz, E. K. (2008). Learners' perceptions of how anxiety interacts with personal and instructional factors to influence their achievement in English: A qualitative analysis of EFL learners in China. Language learning, 58(1), 151-183. https://doi.org/10.1111/j.1467-9922.2007.00437.x

Ying, Z. (2008). Anxiety and second/foreign language learning revisited. Canadian Journal for New Scholars in Education, 1(1), 1-12.

Young, D. J. (1999). Affect in foreign language and second language learning: A practical guide to creating a low-anxiety classroom atmosphere. Boston, MA: McGraw-Hill.

\section{Copyrights}

Copyright for this article is retained by the author(s), with first publication rights granted to the journal.

This is an open-access article distributed under the terms and conditions of the Creative Commons Attribution license (http://creativecommons.org/licenses/by/4.0/). 